\title{
The necessity of HVAC system for the registered architectural cultural heritage building
}

\author{
Cătălin George Popovici ${ }^{1}$, Sebastian Valeriu Hudișteanu ${ }^{1}$, and Nelu-Cristian Cherecheș ${ }^{1, *}$ \\ 1“Gheorghe Asachi” Technical University of Iaşi, Faculty of Civil Engineering and Building Services, Romania
}

\begin{abstract}
This study is intended to highlight the role of the ventilation and air conditioning system for a theatre. It was chosen as a case study the "Vasile Alecsandri" National Theatre of Jassy. The paper also sought to make a comparison in three distinct scenarios for HVAC Main Hall system - ventilation and air conditioning system of the Main Hall doesn't work; only the ventilation system of the Main Hall works and ventilation and air conditioning system of the Main Hall works. For analysing the comfort parameters, the ANSYS-Fluent software was used to build a 2D model of the building and simulation of HVAC system functionality during winter season, in all three scenarios. For the studied scenarios, the external conditions of Jassy and the indoor conditions of the theatre, when the entire spectacle hall is occupied were considered. The main aspects evaluated for each case were the air temperature, air velocity and relative humidity. The results are presented comparatively as plots and spectra of the interest parameters.
\end{abstract}

\section{Introduction}

The functionality of the HVAC system and other building services is a very important target for all type of buildings and even more for locations with high density of people, such as theatres.

An important and prestigious objective of Jassy is "Vasile Alecsandri" National Theatre, one of the most representative historical monuments of the city, rehabilitated and consolidated until 2012.

The "Vasile Alecsandri" National Theatre of Jassy was built between 1894 and 1896 on the site of the old town hall that was demolished $[1,2]$. The project is the work of the Viennese architects Fellner and Helmer and the construction was carried out by the Construction Society of Bucharest. "Vasile Alecsandri" National Theater of Jassy is considered to be the oldest and most beautiful place of its kind in Romania.

HVAC system is one of the most important building services system of this famous theatre. Initial HVAC project was designed in 1896 by Koerting brothers in Paris and they only solved the problems of heating using natural circulation air combined with mechanical ventilation using a large pressured room. The existing installations have never been dimensioned for cooling [1, 2].

The new project solution of the engineering thermotechnical system included the system of insuring higher microclimatic conditions for the pleasant stay of visitors as well as actors and technical staff. Special care was given to the auditorium and to the stage. The previous solutions of heating and ventilation system with the new project were raised to a different comfort level with HVAC system. Under these circumstances and according to scientific literature specifications, the HVAC solution implemented for "Vasile Alecsandri" National Theatre of Jassy consists in four HVAC integrated systems serving: Main Hall, stage, foyer and adjacent areas [2]. It is a multi-zone solution which divides the building into 3 areas whose utilization is never simultaneous: Zone 1 - Main hall - stall, lodges and balcony; Zone 2 - stage and orchestra pit; Zone 3 foyer and adjacent areas [6].

The HVAC technical data for the building are the following [2]:

- Total surface - $11.300 \mathrm{~m}^{2}$;

- Capacity - 740 places;

- Total heating power - $800 \mathrm{~kW}$;

- Boilers - 2 units;

- Total cooling power - $350 \mathrm{~kW}$;

- Air chiller - 1 unit;

- Total supply airflow - $33000 \mathrm{~m}^{3} / \mathrm{h}$;

- Total exhaust airflow - $38000 \mathrm{~m}^{3} / \mathrm{h}$;

- Air handling unit - 6 units;

- Exhaust fan - 8 units.

\section{Case description}

The subject of this study is the Main Hall of "Vasile Alecsandri" National Theatre of Jassy - the space where the entire audience is present during spectacles. This represents a voluminous space with $10.7 \mathrm{~m}$ height, $18 \mathrm{~m}$ width and $21 \mathrm{~m}$ length.

The ventilation of the Main Hall is realized by using three independent systems for introducing the fresh air in different zones: stall, lodges and balcony. The exhaust air is evacuated through one system, placed under the

* Corresponding author: chereches@tuiasi.ro

(C) The Authors, published by EDP Sciences. This is an open access article distributed under the terms of the Creative Commons Attribution License 4.0 (http://creativecommons.org/licenses/by/4.0/). 
roof. The total airflow in the auditorium Main Hall is of $21,000 \mathrm{~m}^{3} / \mathrm{h}$. The ventilation is balanced, meaning that the introduced airflow is equal with the evacuated one.

The problem studied consist of the functionality of the HVAC system during the theatre show, in winter time, for three distinct scenarios:

First scenario - Ventilation and air conditioning system of the Main Hall doesn't work;

Second scenario - Only the ventilation system of the Main Hall works;

Third scenario - Ventilation and air conditioning system of the Main Hall works.

\section{Numerical modelling}

The comfort parameters were analysed numerically using the ANSYS-Fluent software for a 2D model of the building and the simulation of HVAC system functionality during winter time, in all three scenarios. A 2D model of the building was realized by using ANSYSFluent software, simulating the functionality of the HVAC system. For the studied scenarios, the external conditions of Jassy and the indoor conditions of the theatre, when the entire spectacle hall is occupied were considered. The main aspects evaluated for each case were the air temperature, air velocity and relative humidity.

The simulations are achieved in steady state regime, using turbulent flow and $\mathrm{k}-\varepsilon$ model $[7,8,9]$. Therefore, the temperature, velocity and relative humidity data inside the main hall of the theatre were obtained. Performing numerical simulations carried out by CFD tool, ANSYS-Fluent, the differential equations of heat transfer and fluid mechanics were solved [3]:

Momentum equation:

$$
\frac{\delta}{\delta t}(\rho \vec{v})+\nabla \cdot(\rho \overrightarrow{v v})=-\nabla p+\nabla(\bar{\tau})+\rho \vec{g}+\vec{F}
$$

Energy conservation:

$$
\frac{\delta}{\delta t}(\rho E)+\nabla \cdot(\vec{v}(\rho E+p))=-\nabla \cdot\left(\sum_{j} h_{j} J_{j}\right)+S_{h}
$$

Conservation of mass:

$$
\frac{\delta p}{\delta t}+\nabla \cdot(\rho \vec{v})=S_{m}
$$

The geometry and mesh of the model, Fig. 1, were realized by using ANSYS-Design-Modeller and ANSYS-Meshing. The geometry of the building is a simplified one, for the cross section only, assuming a 2D model. It was determined the mass flow for each grille, taking into account that Fluent uses an auxiliary virtual dimension of $1 \mathrm{~m}$ long [3]. The mesh was created with refinements near walls, Fig. 2.b, resulting in 5596 nodes, 10418 2D interior faces and 5322 mixed cells.

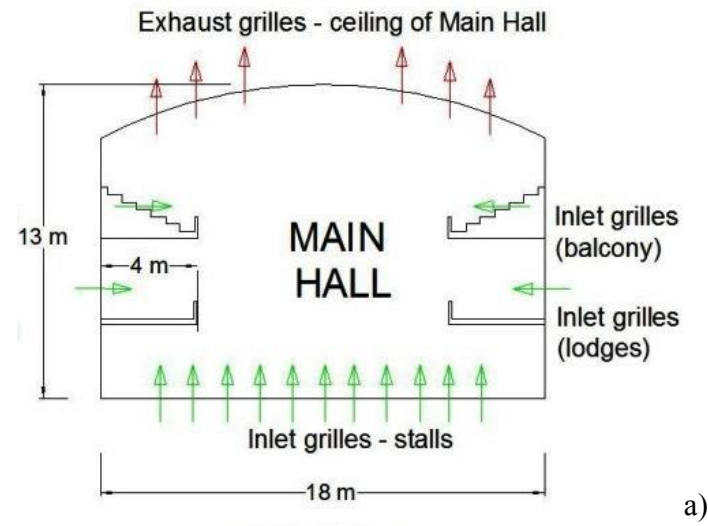

a)

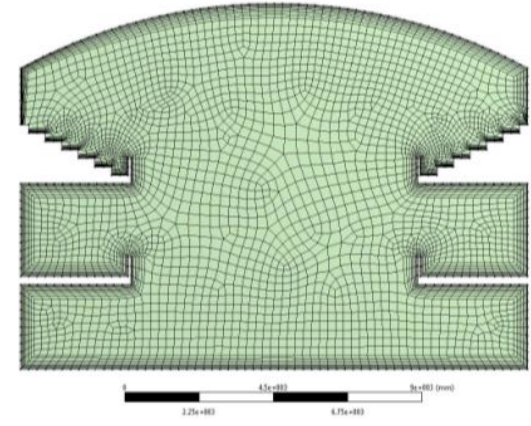

b)

Fig. 1. Cross section of the Main Hall: a) geometry of the 2D model; b) meshing.

The input data are the following:

- inlet sections, the conditioned fresh air temperature of $20^{\circ} \mathrm{C}$;

- $\quad$ outlet sections are set as outflow zones;

- $\quad$ exterior air temperature $T_{\text {ext }}=-18^{\circ} \mathrm{C}$;

- $\quad$ convective heat transfer coefficient $\alpha=24 \mathrm{~W} / \mathrm{m}^{2} \mathrm{~K}$;

- $\quad$ flow regime - turbulent ( $k-\varepsilon \mathrm{RNG})$;

- modelling humidity - species model;

- two volumetric species: air and water-vapours;

- moisture for a sitting person: $70 \mathrm{~g} \mathrm{H}_{2} \mathrm{O} / \mathrm{h}[4,5,10]$.

\section{Results}

The results are presented comparatively for the three studied scenarios. The qualitative data are revealed by contours of velocity, temperature and humidity, while the quantitative ones can be observed in the plots of the same parameters.

\subsection{First Scenario - Ventilation and air conditioning system of the Main Hall doesn't work}

All the air handling units are out of order or doesn't work in this first case. There are 740 peoples inside the Main Hall during the show, without fresh air, heating or cooling. Fig. 2 highlights the first Scenario temperature distribution.

More accurate data is presented in Fig. 2.a, which offers information about temperature distribution at different height in cross section. The elevation planes were selected as $\mathrm{h}=1 \mathrm{~m}, 4 \mathrm{~m}, 7.5 \mathrm{~m}, 9 \mathrm{~m}$ and $10.7 \mathrm{~m}$, being most relevant from the point of view of human comfort in occupational zones. 

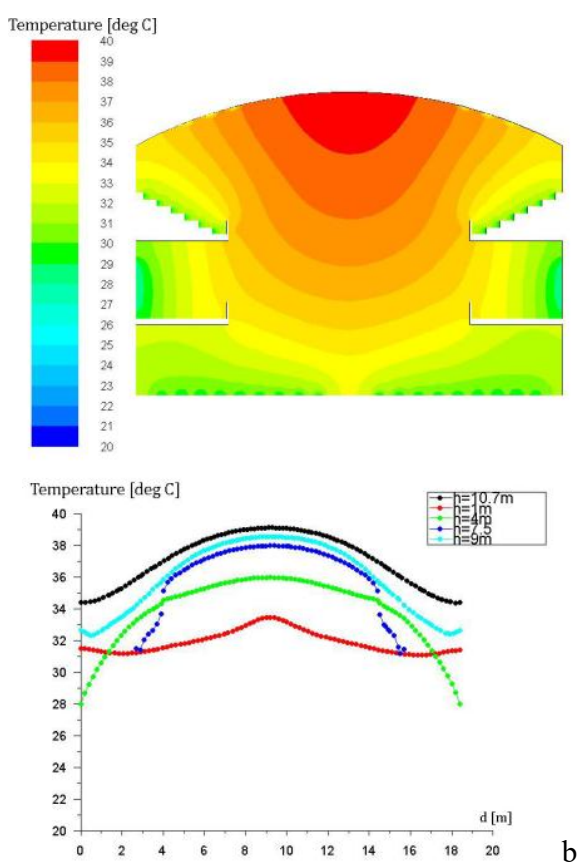

a)

b)

Fig. 2. The first scenario indoor temperature distribution: a) Temperature spectra; b) Temperatures at different heights.

Indoor air temperatures reach values of $28-39{ }^{\circ} \mathrm{C}$ and of $28-34{ }^{\circ} \mathrm{C}$ for stall, lodges and balcony areas. The thermal discomfort is maximum. The indoor air is almost impossible to breathe.

Fig. 3 shows the velocities spectra and velocity of the indoor air at different heights. All the values are near zero. Very quiet but too hot.

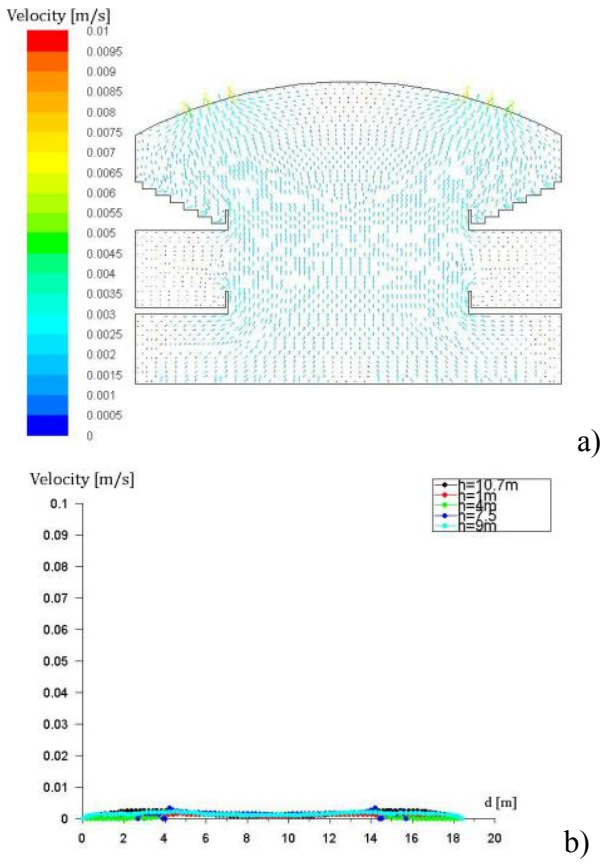

a)

b)

Fig. 3. The first scenario velocity distribution: a) Velocity spectra; b) Velocity at different heights.

The values of indoor relative humidity lie between 65 $75 \%$, Fig 4 . The maximum values are recorded at the top of the balcony and the risk of condensation is the greatest.

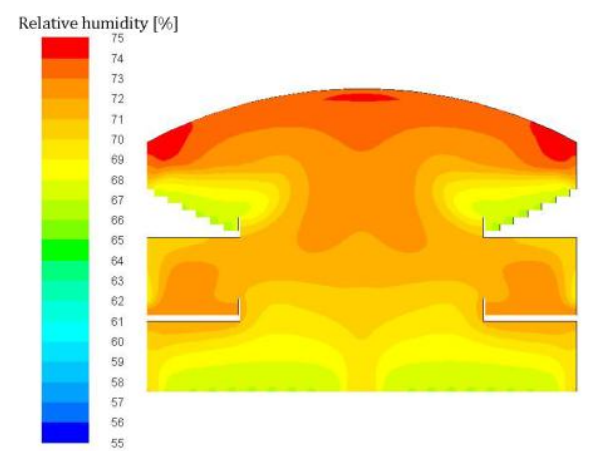

Fig. 4. The first scenario - Indoor relative humidity spectra.

\subsection{Second scenario - Only the ventilation system of the Main Hall works.}

Only the ventilation system works in the second scenario. The Main Hall capacity is full with 740 peoples inside and only the fresh air is provided. The cooling system doesn't work.

Fig. 5 shows the second Scenario temperature distribution.
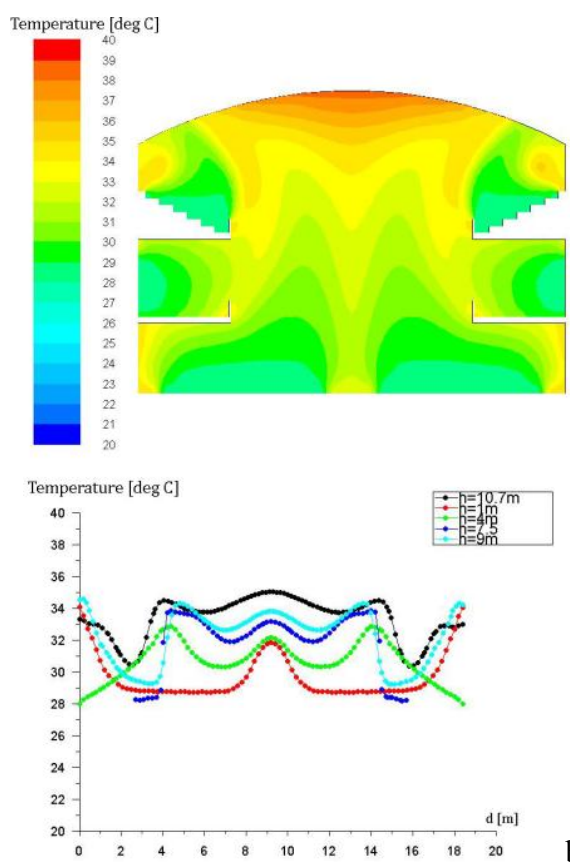

a)

b)

Fig. 5. The second scenario indoor temperature distribution: a) Temperature spectra; b) Temperatures at different heights.

The range of the indoor air temperatures values are of 27 - $35{ }^{\circ} \mathrm{C}$ and of $27-31{ }^{\circ} \mathrm{C}$ for stall, lodges and balcony areas. Thermal discomfort is felt.

The average velocity is around $0.3 \mathrm{~m} / \mathrm{s}$, Fig. 6, and doesn't affect the comfort of the occupants. 

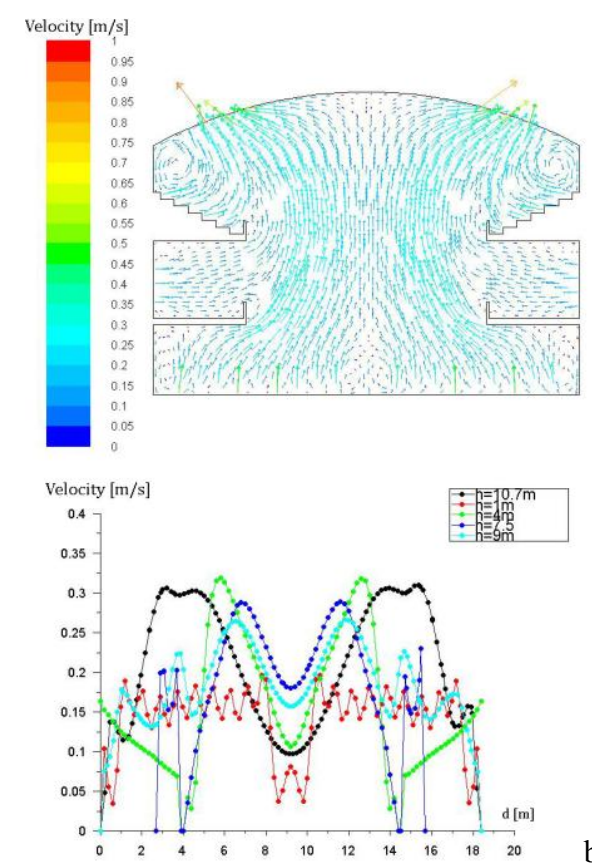

a)

Fig. 6. The second scenario indoor velocities distribution: a) Velocity spectra; b) Velocity at different heights.

The indoor relative humidity value is between of $65-70$ $\%$, Fig 7 . The maximum values are recorded at the top of the balcony.

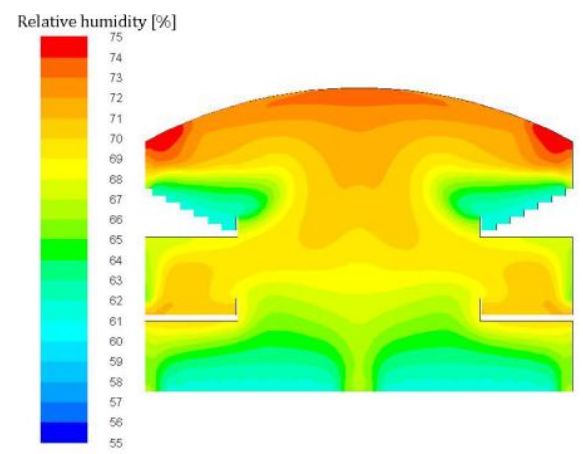

Fig. 7. The second scenario - Indoor relative humidity spectra.

Third scenario - Ventilation and air conditioning system of the Main Hall works.

All the air handling units are in use, so ventilation and air conditioning system of the Main Hall works in this third case. There are 740 peoples inside the Main Hall during the theatre show, enjoying fresh air, heating and cooling. Humidity control works too.

Fig. 8 shows the third scenario temperature distribution.

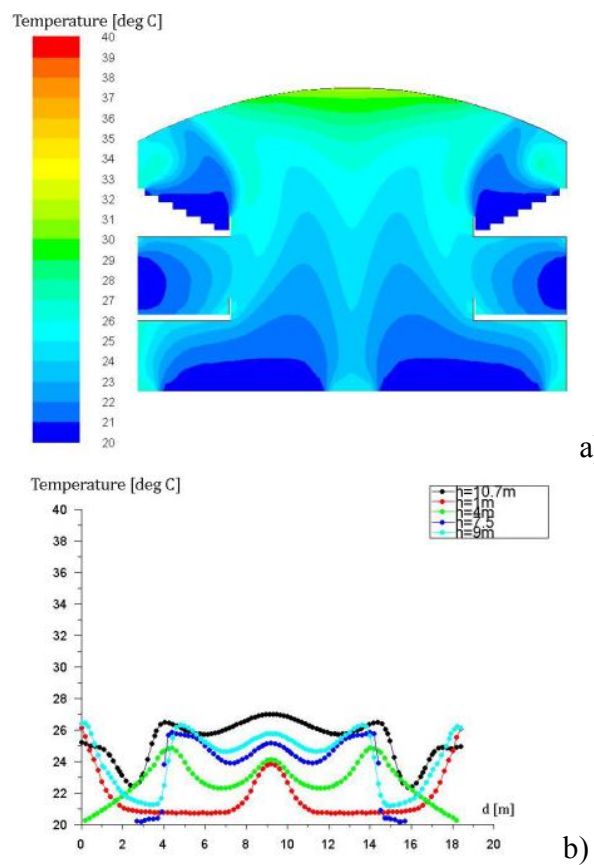

a)

Fig. 8. The third scenario indoor temperature distribution: a) Temperature spectra; b) Temperatures at different heights.

The range indoor air temperatures values are of $22-27$ ${ }^{\circ} \mathrm{C}$ and of $22-25{ }^{\circ} \mathrm{C}$ for stall, lodges and balcony areas. All the thermal comfort parameters are optimal.

The average velocity in around of $0.3 \mathrm{~m} / \mathrm{s}$, Fig. 9, and doesn't affect the comfort of the occupants.

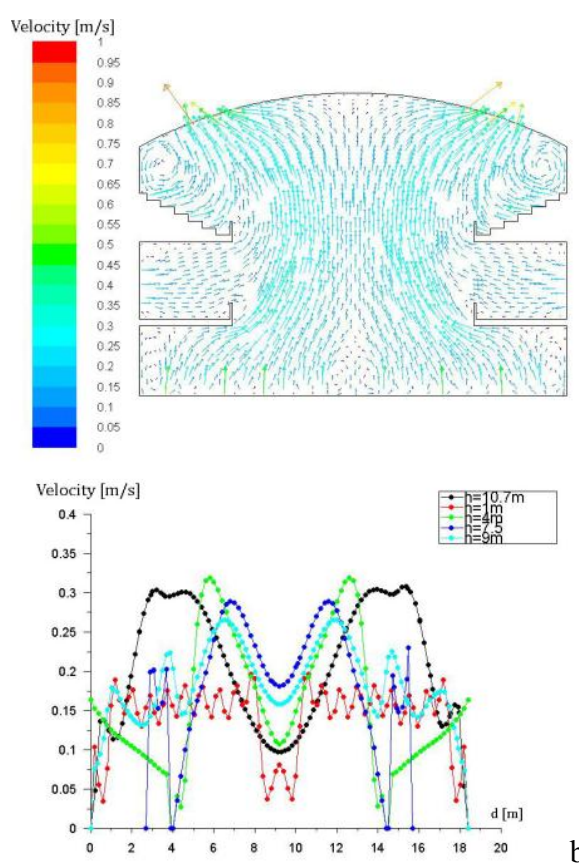

a)

Fig. 9. The third scenario indoor velocities distribution: a) Velocity spectra; b) Velocity at different heights.

Fig. 10 shows that the indoor relative humidity value is between of $55-60 \%$. 


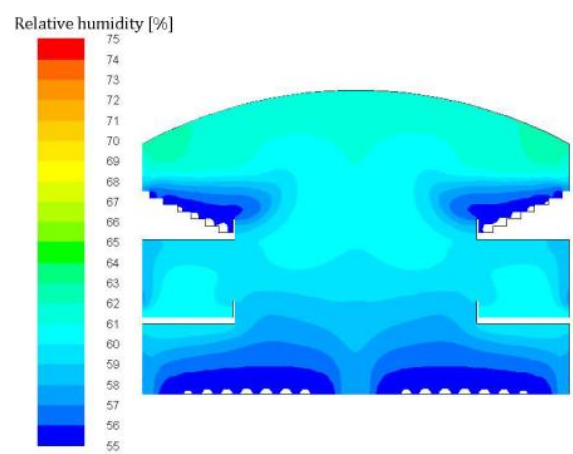

Fig. 10. The third scenario - Indoor relative humidity spectra.

\section{Conclusions}

The Main Hall HVAC system of the real building "Vasile Alecsandri" National Theatre of Jassy was studied by using a 2D model, with specific software ANSYS-Fluent.

The Main Hall HVAC system is subjected to an analysis of its functionality, by evaluating the supplied parameters when operating in three different scenarios as follows:

First scenario - Ventilation and air conditioning system' of the Main Hall doesn't work;

Second scenario - Only the ventilation system of the Main Hall works;

Third scenario - Ventilation and air conditioning system of the Main Hall works.

When the ventilation and air conditioning system of the Main Hall doesn't work, the indoor air is almost impossible to breathe. The indoor air temperatures are between of $28-35^{\circ} \mathrm{C}$, indoor air velocities are near zero and indoor relative humidity varies between $65-75 \%$. The thermal discomfort is maximum.

The ventilation system of Main Hall works in the second scenario and the thermal discomfort is felt. The indoor air temperatures reach values of $27-31{ }^{\circ} \mathrm{C}$, indoor air velocities values are around $0.3 \mathrm{~m} / \mathrm{s}$ and indoor relative humidity is lies between $65-70 \%$. The indoor air temperature and relative humidity values exceed the limits of thermal comfort.

The ventilation and air conditioning system of the Main Hall works in this third scenario and the thermal comfort parameters are optimal. The indoor air temperatures are between of $22-25{ }^{\circ} \mathrm{C}$, indoor air velocities values around $0.3 \mathrm{~m} / \mathrm{s}$ and indoor relative humidity varies between $65-70 \%$.

The recently implemented HVAC Main Hall system reaches its task and provides adequate comfort conditions.

After an overall outlook of the results, it can be stated with certainty that it is not possible to have a theatre show on Main Hall of "Vasile Alecsandri" National Theatre of Jassy without ventilation and air conditioning system. This is the main conclusion of the study and it doesn't conceive of a theatre without the operation of the ventilation and air conditioning system. In any season the humidity control is another need for registered architectural cultural heritage buildings to ensure the integrity of paintings and conserving the original architectural elements of the buildings.

This study confirms the necessity of HVAC system for the registered architectural cultural heritage building and theatres in a particular case.

\section{Notations}

$p$ - Pressure $(\mathrm{Pa})$;

$\alpha$ - convective heat transfer coefficient $\left(\mathrm{W} / \mathrm{m}^{2} \cdot \mathrm{K}\right)$;

$v$ - Overall velocity vector $(\mathrm{m} / \mathrm{s})$;

$t$ - Time (s);

$\rho$ - Density $\left(\mathrm{kg} / \mathrm{m}^{3}\right)$;

$\tau$ - Shear stress $(\mathrm{Pa})$;

$g$ - Gravitational acceleration $\left(\mathrm{m} / \mathrm{s}^{2}\right)$;

$F$ - Force vector $(\mathrm{N})$;

$E$ - Total energy $(\mathrm{J})$;

$h$ - Enthalpy $(\mathrm{J} / \mathrm{kg})$;

$h_{0}$ - Standard state enthalpy of formation (energy/mass, energy/mole);

$J$ - Mass flux; diffusion flux $\left(\mathrm{kg} / \mathrm{m}^{2} \cdot \mathrm{s}\right)$;

$S_{h}$ - Source of heat added;

$S_{m}$ - Source of mass added to the continuous phase;

$T_{\text {ext }}$ - temperature of external air $\left({ }^{\circ} \mathrm{C}\right)$.

\section{References}

1. National Archives of Romania, 2007.

2. Project and Execution of the Construction, 2012.

3. ANSYS-Fluent 13.0, Theory Guide.

4. Peri A., Fernandes P. M., Vishwanadha C., Numerical simulation of air flow in a general ward of a hospital. IJRRAS 8, 400 - 444 (2011).

5. Balocco C., Petrone G., Cammarata G., Vitali P., Albertini R., Pasquarella C., Indoor Air Quality in a Real Operating Theatre under Effective Use Conditions. Biomedical Science and Engineering, 866 - 883 (2014).

6. Popovici CG, Hudișteanu SV., Numerical simulation of HVAC system functionality in a sociocultural building, Procedia Technology 22; 2016, p. 535-542.

7. Thiyagarajan G. M., Raj Kumar S., Velocity optimisation using computational fluid dynamics as a tool in leed rated building to reduce energy consumption. Journal of Chemical and Pharmaceutical Sciences, 142 145 (2015).

8. Uyttenhove W., De Paepe M., Janssens A., CFD-modelling of Temperature and Humidity Distribution in the St. Pieter's Church. IAEAnnex 41, Subtask 1, 2004.

9. Mahu R., Popescu F., Ion I. V., CFD Modeling Approach for HVAC Systems Analysis. Chemical Bulletin of "Politehnica" University of Timisoara, 69 - 73 (2012).

10. Bronström T., Fundamentals of indoor climate at the seminar in Riga regarding Indoor Climate in Churches - Problems and solutions, 2004. 